\title{
QUANTUM CHEMICAL STUDIES, SPECTROSCOPIC ANALYSIS AND MOLECULAR STRUCTURE INVESTIGATION OF 4-CHLORO-2-[(FURAN-2-YLMETHYL)AMINO]-5-SULFAMOYLBENZOIC ACID
}

\author{
C. Charanya1, S. Sampathkrishnan ${ }^{2}$, N. Balamurugan ${ }^{3, *}$ \\ ${ }^{1}$ Research Scholar, Department of Physics, Sri Venkateshwara College of Engineering, \\ Sriperumbudur 602105, Tamil Nadu, India \\ ${ }^{2}$ Department of Physics, Sri Venkateshwara College of Engineering, Sriperumbudur 602105, \\ Tamil Nadu, India \\ ${ }^{3 *}$ Department of Physics, Dhanalakshmi College of Engineering, Tambaram, Chennai, \\ Tamil Nadu, India \\ n_rishibalaa@yahoo.co.in
}

\begin{abstract}
In this study, the FTIR, FT-Raman and UV-visible Spectra of furosemide molecule, $\mathrm{C}_{12} \mathrm{H}_{11} \mathrm{ClN}_{2} \mathrm{O}_{5} \mathrm{~S}$ (with named, 4-chloro-2-[(furan-2-ylmethyl)amino]-5-sulfamoylbenzoic acid), were recorded experimentally and theoretically. The optimized geometrical structure, harmonic vibration frequencies, and chemical shifts were computed using a hybrid-DFT (B3LYP) method and 6-31G(d,p) as the basis set. The complete assignments of fundamental vibrations were performed on the basis of the experimental results and Total Energy Distribution (TED) of the vibrational modes. The first order hyperpolarizability and relative properties of furosemide were calculated. The UV-Visible spectrum of the compound was recorded in the range $200-400 \mathrm{~nm}$ and the electronic properties, such as HOMO and LUMO energies, were determined by Time-Dependent DFT approach. Furthermore, Mulliken population analysis and thermodynamic properties were performed using B3LYP/6-31G $(\mathrm{d}, \mathrm{p})$ level for the furosemide compound.
\end{abstract}

Keywords: DFT; TED; UV-Vis; HOMO-LUMO

\section{КВАНТНОХЕМИСКА СТУДИЈА, СПЕКТРОСКОПСКА АНАЛИЗА И ИСПИТУВАЊЕ \\ НА МОЛЕКУЛСКАТА СТРУКТУРА} НА 4-ХЛОРО-2-[(ФУРАН-2-ИЛМЕТИЛ)АМИНО]-5-СУЛФАМОИЛБЕНЗОЕВА КИСЕЛИНА

Во оваа студија беа експериментално снимени и теориски пресметани FTIR, FT-Raman и $\mathrm{UV}$-vis спектрите на фуросемидната молекула $\mathrm{C}_{12} \mathrm{H}_{11} \mathrm{ClN}_{2} \mathrm{O}_{5} \mathrm{~S}$ (именувана 4-хлоро-2-[(фуран-2илметил)амино]-5-сулфамоилбензоева киселина). Оптимизираната геометриска структура, хармониските вибрациони фреквенции и хемиските поместувања беа определени со хибриден метод на DFT (B3LYP) и базисен сет 6-31G(d,p). Целосната асигнација на фундаменталните вибрации беше извршена врз основа на експерименталните резултати и вкупната енергетска распределба (TED) на вибрационите модови. Беа пресметани хиперполаризабилноста од прв ред и релативните својства на фуросемидот. Беше снимен UV-Vis спектарот на соединението во опсегот од 200-400 nm и беа определени електронските својства како што се енергиите HOMO и LUMO по пат на временски зависен приод на DFT. Покрај тоа, беше извршена популациона анализа по Mulliken и беа определени термодинамички својства со примена на B3LYP/6-31G(d,p) ниво за фуросемидното соединение.

Клучни зборови: DFT; TED; UV-Vis; HOMO-LUMO 


\section{INTRODUCTION}

Furosemide is a potent diuretic drug commonly used in adults, children and infants, for the management of excessive fluid accumulation and edema caused by congestive heart failure, renal disease, and cirrhosis of the liver. In adults, oral FURO may be used alone, or in combination with different antihypertensive agents, for the treatment of hypertension [1]. In addition, the unsubstituted aromatic/heterocyclic sulphonamides act as carbonic anhydrase inhibitors $[2,3]$ whereas other types of derivatives show diuretic activity (high-ceiling diuretics or thiadiazine diuretics), hypoglycemic activity, and anticancer properties [4]. Due to their significant pharmacology applications and widespread use in medicine, these compounds have gained attention in bio-inorganic and metal-based drug chemistry. Inter- and intramolecular hydrogen bonding interactions [5-7] have thus received an increased attention, both from a practical and a theoretical point of view, in determining the structure and activity of the biological molecule [8].

The Becke-3-Lee-Yang-Parr (B3LYP) functional provides an excellent agreement between the accuracy and computational efficiency of vibrational spectra of bioactive molecules [9-11]. A literature survey reveals that, to the best of our knowledge, the results based on quantum chemical calculations, vibrational spectral studies and HOMO-LUMO analysis on furosemide has not been reported. Hence, we wanted to make a spectroscopic characterization of the furosemide molecule with a view to get some insight into the structure function relationship through spectra-structure correlation. In order to achieve this objective, FT-Raman, FTIR and UVvisible spectroscopic studies, along with HOMO (the highest occupied molecular orbital) - LUMO (lowest unoccupied molecular orbital) analysis have been performed by applying density functional theory calculations based on Becke3-Lee-Yang-Parr (B3LYP) with 6-31G(d,p) as a basis set. Quantum chemical computational methods have proved to be an essential tool for interpreting and predicting the vibrational spectra $[12,13]$.

\section{EXPERIMENTAL DETAILS}

The furosemide compound, acquired from Lancaster Chemical Company, UK. was utilized accordingly for the spectral measurements. The FT-IR range of furosemide was recorded in a Bruker IFS $66 \mathrm{~V}$ spectrometer in the scope of $4000-400 \mathrm{~cm}^{-1}$. The range was recorded at room temperature with a filtering velocity of $30 \mathrm{~cm}^{-1}$ $\min ^{-1}$ and the spectral resolution of $\pm 2 \mathrm{~cm}^{-1}$. The FT-Raman range of furosemide was additionally recorded in the scope of $4000-100 \mathrm{~cm}^{-1}$ utilizing a similar instrument with a FRA 106 Raman module furnished with a Nd:YAG laser source, working at $1.064 \mu \mathrm{m}$ line widths with $200 \mathrm{~mW}$ control. The frequencies of every single sharp band are precise to $\pm 1 \mathrm{~cm}^{-1}$. The ultraviolet absorption range of furosemide solved in water was analyzed in the range $200-400 \mathrm{~nm}$ by utilizing a Cary $5 \mathrm{E}$ UV visible NIR recording spectrometer. All the spectral measurements were completed at the Indian Institute of Technology, Chennai, India.

\section{COMPUTATIONAL DETAILS}

In the present work, the Density Functional Theory (DFT/B3LYP) at the $6-31 \mathrm{G}(\mathrm{d}, \mathrm{p})$ basis set level was adopted to calculate the properties of the furosemide molecule. All the calculations were performed using the Gaussian 09W program package [14] with the default convergence criteria without any constraint on the geometry [15]. The equilibrium geometry corresponding to the true minimum on the Potential Energy Surfaces (PES) has been obtained by effectively solving selfconsistent field equations. The vibrational spectra of the furosemide were obtained by taking the second derivative of energy, computed analytically by the use of Total Energy Distribution (TED) using the SQM program $[16,17]$, along with the available related molecule.

\section{RESULTS AND DISCUSSION}

\subsection{Geometric structure}

The first task for the computational work was to determine the optimized geometry of the studied molecule. The optimized molecular structure of furosemide with the numbering scheme of the atoms was obtained from the Gauss View program [18]. The optimized geometrical parameters of furosemide calculated by DFT-B3LYP level with the $6-31 \mathrm{G}(\mathrm{d}, \mathrm{p})$ basis set are listed in Table 1, which are in accordance with the atom numbering scheme given in Figure 1.

From the theoretical values one can find that most of the optimized bond lengths are larger than the experimental values. This overestimation can be explained in that the theoretical calculations belong to the isolated molecule in the gaseous phase and the experimental results belong to the molecules in the solid state. 
Table 1

The calculated geometrical parameters of 4-chloro-2-[(furan-2-ylmethyl)amino]-5-sulfamoylbenzoic acid bond lengths in angstrom $(A)$ and angles in degrees $\left({ }^{\circ}\right)$

\begin{tabular}{|c|c|c|c|}
\hline Bond lengths & Calculated values & Bond angles $\left(^{\circ}\right)$ & Calculated values \\
\hline $\mathrm{C} 1-\mathrm{C} 2$ & 1.486 & $\mathrm{C} 2-\mathrm{C} 1-\mathrm{O} 8$ & 120.058 \\
\hline $\mathrm{C} 1-\mathrm{O} 8$ & 1.227 & C2-C1-O9 & 124.526 \\
\hline C1-O9 & 1.349 & $\mathrm{C} 1-\mathrm{C} 2-\mathrm{C} 3$ & 122.376 \\
\hline $\mathrm{C} 2-\mathrm{C} 3$ & 1.414 & $\mathrm{C} 1-\mathrm{C} 2-\mathrm{C} 7$ & 118.417 \\
\hline $\mathrm{C} 2-\mathrm{C} 7$ & 1.408 & O8-C1-O9 & 115.416 \\
\hline $\mathrm{C} 3-\mathrm{C} 4$ & 1.408 & $\mathrm{C} 3-\mathrm{C} 2-\mathrm{C} 7$ & 119.207 \\
\hline C3-C14 & 1.400 & $\mathrm{C} 2-\mathrm{C} 3-\mathrm{C} 4$ & 118.272 \\
\hline $\mathrm{C} 4-\mathrm{C} 5$ & 1.395 & C2-C3-C14 & 120.836 \\
\hline $\mathrm{C} 4-\mathrm{H} 22$ & 1.101 & $\mathrm{C} 2-\mathrm{C} 7-\mathrm{C} 6$ & 122.353 \\
\hline C5-C6 & 1.405 & $\mathrm{C} 2-\mathrm{C} 7-\mathrm{H} 23$ & 119.029 \\
\hline $\mathrm{C} 5-\mathrm{Cl} 21$ & 1.729 & $\mathrm{C} 4-\mathrm{C} 3-\mathrm{C} 14$ & 120.892 \\
\hline C6-C7 & 1.398 & $\mathrm{C} 3-\mathrm{C} 4-\mathrm{C} 5$ & 121.734 \\
\hline C6-S10 & 1.810 & $\mathrm{C} 3-\mathrm{C} 4-\mathrm{H} 22$ & 119.698 \\
\hline C7-H23 & 1.102 & C3-C14-C15 & 125.536 \\
\hline $\mathrm{O} 9-\mathrm{H} 24$ & 0.971 & C3-C14-H27 & 116.717 \\
\hline $\mathrm{S} 10-\mathrm{O} 11$ & 1.453 & $\mathrm{C} 5-\mathrm{C} 4-\mathrm{H} 22$ & 118.568 \\
\hline $\mathrm{S} 10-\mathrm{O} 12$ & 1.452 & $\mathrm{C} 4-\mathrm{C} 5-\mathrm{C} 6$ & 120.382 \\
\hline S10-N13 & 1.689 & $\mathrm{C} 4-\mathrm{C} 5-\mathrm{H} 21$ & 117.561 \\
\hline $\mathrm{N} 13-\mathrm{H} 25$ & 1.019 & C6-C5-H21 & 122.055 \\
\hline N13-H26 & 1.019 & $\mathrm{C} 5-\mathrm{C} 6-\mathrm{C} 7$ & 118.027 \\
\hline N14-C15 & 1.474 & C5-C6-S10 & 123.456 \\
\hline N14-H27 & 1.046 & C7-C6-S10 & 118.499 \\
\hline $\mathrm{C} 15-\mathrm{C} 17$ & 1.504 & C6-C7-H23 & 119.029 \\
\hline C15-H28 & 1.114 & C6-S10-O11 & 107.683 \\
\hline $\mathrm{C} 15-\mathrm{H} 29$ & 1.114 & C6-S10-O12 & 108.277 \\
\hline O16-C17 & 1.368 & C6-S10-N13 & 109.223 \\
\hline $\mathrm{O} 16-\mathrm{C} 20$ & 1.362 & O11-S10-O12 & 116.021 \\
\hline C17-C18 & 1.367 & O11-S10-O13 & 107.774 \\
\hline C18-C19 & 1.431 & O12-S10-O13 & 108.981 \\
\hline C18-H30 & 1.095 & $\mathrm{~S} 10-\mathrm{O} 13-\mathrm{H} 25$ & 110.919 \\
\hline C19-C20 & 1.360 & $\mathrm{H} 25-\mathrm{O} 13-\mathrm{H} 26$ & 111.479 \\
\hline C19-H31 & 1.096 & C15-N14-H27 & 117.744 \\
\hline C20-H32 & 1.094 & N14-C15-C17 & 111.096 \\
\hline \multirow[t]{7}{*}{ O9-H27 } & 1.882 & N14-C15-H28 & 110.108 \\
\hline & & N14-C15-H29 & 109.690 \\
\hline & & C17-C15-H28 & 108.032 \\
\hline & & $\mathrm{C} 17-\mathrm{C} 15-\mathrm{H} 29$ & 108.051 \\
\hline & & $\mathrm{C} 15-\mathrm{O} 16-\mathrm{C} 17$ & 121.902 \\
\hline & & C15-C17-C18 & 128.335 \\
\hline & & $\mathrm{H} 28-\mathrm{C} 15-\mathrm{H} 29$ & 109.820 \\
\hline
\end{tabular}

The changes in the bond length of the $\mathrm{C}-\mathrm{H}$ bond of the substituents may be of the electron withdrawing type $(\mathrm{Cl}, \mathrm{F}, \mathrm{Br}$, etc.) due to a change in the charge distribution on the carbon atom of the benzene ring, as has been explained by many authors [19-22]. The carbon and hydrogen atoms are bonded with a $\sigma$-bond in the benzene ring, and the substitution of a halogen reduces the electron den- sity of the $\mathrm{C}$ atom. Therefore, substitution with $\mathrm{Cl}$, $\mathrm{Br}$ or $\mathrm{F}$ at the $\mathrm{C}(5)$ atom, which shares its $p$ electron with the ring, leads to some changes of the bond lengths and bond angles in the aromatic ring. It is well known that DFT methods predict bond lengths which are systematically too long, particularly the C-H and N-H bond lengths [23]. The theoretical bond lengths of $\mathrm{C}-\mathrm{H}$ are in the range from 
1.095 to $1.102 \AA$. Likewise, the calculated bond lengths of $\mathrm{N}-\mathrm{H}$ are in the range from 1.01 to $1.11 \AA$. The calculated bond lengths of $\mathrm{C}=\mathrm{C}$ fall in the range from 1.395 to $1.405 \AA$. For the benzenesulfonamide molecule, these bond lengths were found in the range 1.339 to $1.407 \AA$ [24]. The computational method, B3LYP, which includes electron correlation effects, strongly overestimates all the bond lengths around sulfur [25-27]. In this study, the S-O bond lengths are predicated well by the DFT method.

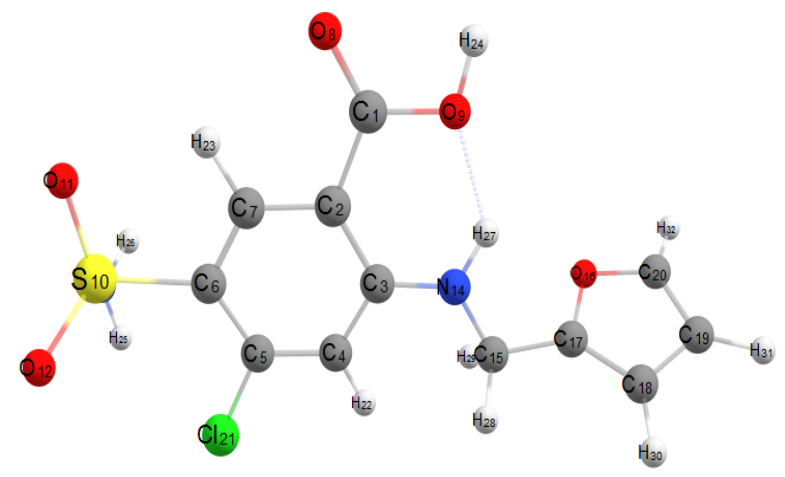

Fig. 1. The optimized geometric structure at the DFT/B3LYP/6-31G(d,p) level of 4-chloro-2-[(furan-2ylmethyl)amino]-5-sulfamoylbenzoic acid

Substitution with halogen atoms and $\mathrm{SO}_{2}$ leads to some changes of the bond angles in the aromatic ring. The $\mathrm{C}(5)-\mathrm{C}(6)-\mathrm{C}(7)$ angle at the position of the $\mathrm{SO}_{2}$ substituent, and the $\mathrm{C}(4)-\mathrm{C}(5)$ $\mathrm{C}(6)$ angle at the position of the halogen substituent, are larger $\left(118.01^{\circ}\right.$ and $120.30^{\circ}$, respectively), and the others are smaller than the typical hexagonal angle of $120^{\circ}$.

\subsection{Vibrational assignments}

The optimized structural parameters were used to compute the vibrational frequencies of furosemide at the DFT, B3LYP/6-31G(d,p) level of calculations. The molecule consists of 32 atoms which undergo 90 fundamental modes of vibrations associated with this furosemide molecule. All the 90 vibrations are in agreement with $C_{1}$ symmetry. Vibrational spectral assignments have been carried out on the recorded FTIR and FT-Raman spectra based on the theoretically predicted wavenumbers by B3LYP with the 6-31G(d,p) basis set, and the results, along with their TED values, are presented in Table 2. The experimental and theoretical FTIR and FT-Raman spectra were shown in
Figures 2 and 3. The calculated wavenumbers are all positive values and confirm that the optimized structure of the furosemide molecule is the most stable conformer.

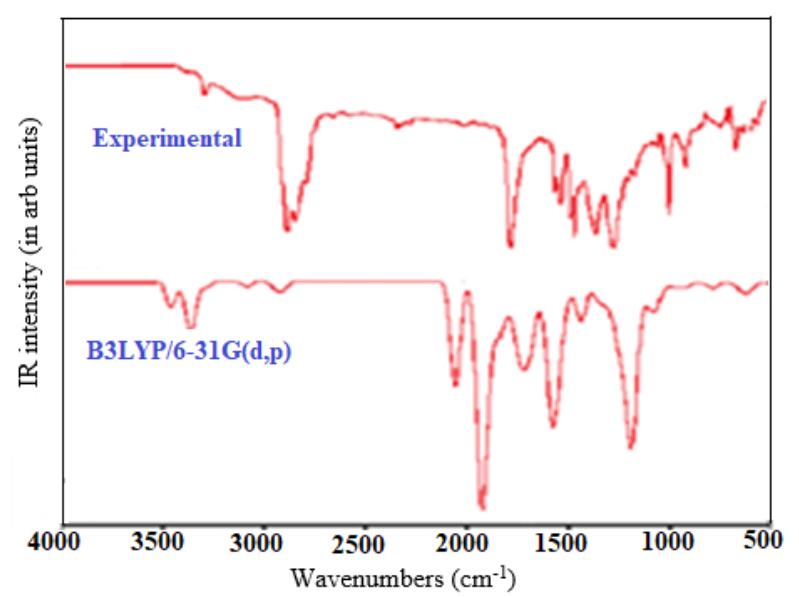

Fig. 2. Experimental and theoretical FTIR spectra of -chloro-2-[(furan-2-ylmethyl)amino]-5-sulfamoylbenzoic acid

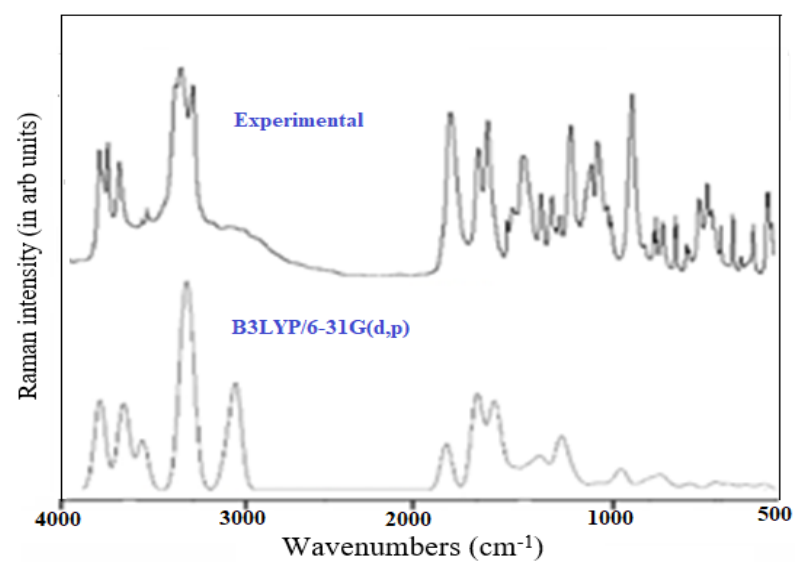

Fig. 3. Experimental and theoretical FT-Raman spectra of chloro-2-[(furan-2-ylmethyl)amino]-5-sulfamoylbenzoic acid

Some bands in the calculated FTIR spectra were not observed in the experimental spectrum. It is imported to note that computed wavenumbers correspond to the gaseous phase of an isolated molecular state, whereas the observed wavenumbers correspond to the solid state spectra. In order to determine the correlations between the calculated and experimental wavenumbers, the linear correlation coefficients $\left(\mathrm{R}^{2}\right)$ values, which were 0.9976 and 0.9962 for the FTIR and FT-Raman wavenumbers of the furosemide molecules, respectively, and the correlation graphics, are given in Figure 4. 
Table 2

Experimental and calculated wavenumbers $\left(\mathrm{cm}^{-1}\right)$ and their assignments of 4-chloro-2-[(furan-2-ylmethyl)amino]-5-sulfamoylbenzoic acid at the B3LYP/6-31G(d,p) level

\begin{tabular}{|c|c|c|c|c|c|}
\hline \multirow{2}{*}{ Modes } & \multicolumn{2}{|c|}{ Experimental } & \multicolumn{2}{|c|}{$\begin{array}{c}\text { DFT/6-31G } \\
\text { Calculated wavenumber }\end{array}$} & \multirow{2}{*}{$\begin{array}{l}\text { Vibrational assignment } \\
\quad(\text { TED }>10 \%)\end{array}$} \\
\hline & FTIR & $\begin{array}{c}\text { FT- } \\
\text { Raman }\end{array}$ & Unscaled & Scaled & \\
\hline 1 & & & 3759.84 & 3616.97 & ט OH (100) \\
\hline 2 & & & 3648.99 & 3510.33 & v OH (99) \\
\hline 3 & & & 3621.75 & 3484.12 & vasym NH2 (100) \\
\hline 4 & 3380 & & 3520.78 & 3386.99 & vsym NH2 (98) \\
\hline 5 & & & 3299.17 & 3173.80 & vsym CH (100) \\
\hline 6 & & 3147 & 3274.31 & 3149.88 & vsym CH (98) \\
\hline 7 & & & 3263.45 & 3139.44 & vsym CH (95) \\
\hline 8 & & & 3245.92 & 3122.57 & vsym CH (94) \\
\hline 9 & & 3107 & 3233.73 & 3110.85 & vasym $\mathrm{CH}_{2}(92)$ \\
\hline 10 & & 2930 & 3051.30 & 2935.35 & vasym $\mathrm{CH}_{2}(98)$ \\
\hline 11 & & 2880 & 2996.29 & 2882.43 & vasym $\mathrm{CH}_{2}(97)$ \\
\hline 12 & 1650 & 1607 & 1817.63 & 1748.56 & u CC (89) \\
\hline 13 & & & 1659.00 & 1595.95 & $v \mathrm{CC}(80)+\beta \mathrm{CH}(15)$ \\
\hline 14 & & 1583 & 1646.56 & 1583.99 & $v \mathrm{CC}(72)+\beta \mathrm{CH}(12)$ \\
\hline 15 & 1556 & & 1615.48 & 1554.09 & v CC (80) \\
\hline 16 & 1531 & 1530 & 1588.35 & 1527.99 & pNH2 (89) \\
\hline 17 & & & 1568.35 & 1508.75 & pNH2 (80) \\
\hline 18 & & & 1533.14 & 1474.88 & $\mathrm{\beta CH}_{2}(67)+v \mathrm{CC}(26)$ \\
\hline 19 & 1456 & 1454 & 1514.16 & 1456.62 & $\beta_{C H}(61)+v \mathrm{CC}(23)$ \\
\hline 20 & 1423 & & 1494.20 & 1437.42 & $v \mathrm{CC}(40)+\beta \mathrm{CH}(37)$ \\
\hline 21 & & & 1460.61 & 1405.11 & $v \mathrm{CC}(39)+\beta \mathrm{CH}(32)$ \\
\hline 22 & 1373 & 1370 & 1431.53 & 1377.13 & $v \mathrm{CC}(36)+\beta \mathrm{CH}(34)$ \\
\hline 23 & & & 1399.38 & 1346.21 & vsym $\mathrm{SO}_{2}(86)$ \\
\hline 24 & 1316 & 1310 & 1364.00 & 1312.16 & vasym $\mathrm{SO}_{2}(48)+v \mathrm{CC}(30)$ \\
\hline 25 & & & 1360.06 & 1308.38 & vasym $\mathrm{SO}_{2}(53)+v \mathrm{CC}(37)$ \\
\hline 26 & & & 1322.05 & 1271.81 & $\beta \mathrm{CH}(71)+v \mathrm{CC}(22)$ \\
\hline 27 & & 1251 & 1303.96 & 1254.41 & vasym $\mathrm{SO}_{2}(40)+v \mathrm{CC}(40)+\beta \mathrm{CH}(10)$ \\
\hline 28 & & & 1293.67 & 1244.51 & $\mathrm{~B} \mathrm{CH}(43)+$ vasym $\mathrm{SO}_{2}(40)$ \\
\hline 29 & & & 1281.91 & 1233.19 & $v \mathrm{CCl}(48)+v \mathrm{CC}(21)+\beta \mathrm{CH}(40)$ \\
\hline 30 & & & 1255.21 & 1207.51 & $\mathrm{~B} \mathrm{CH}(71)+v \mathrm{CC}(19)$ \\
\hline 31 & & & 1233.99 & 1187.10 & $\beta \mathrm{CH}(80)+v \mathrm{CC}(20)$ \\
\hline 32 & 1150 & 1160 & 1185.84 & 1140.78 & $\beta \mathrm{CH}(38)+v \mathrm{CC}(34)$ \\
\hline 33 & & & 1181.02 & 1136.14 & $v \mathrm{CC}(33)+$ vasym $\mathrm{SO}_{2}(40)+\beta \mathrm{CH}(17)$ \\
\hline 34 & & & 1154.40 & 1110.53 & vsym $\mathrm{SO}_{2}(51)$ \\
\hline 35 & & & 1129.85 & 1086.92 & $\beta \mathrm{CH}(71)+v \mathrm{CC}(19)$ \\
\hline 36 & & & 1119.89 & 1077.33 & $\tau \mathrm{NH}_{2}(85)+$ vasym $\mathrm{SO}_{2}(11)$ \\
\hline 37 & & & 1112.34 & 1070.07 & $\tau \mathrm{NH}_{2}(75)+$ vasym $\mathrm{SO}_{2}(10)$ \\
\hline 38 & & & 1094.15 & 1052.57 & $v \mathrm{CC}(28)+$ vasym $\mathrm{SO}_{2}(24)+\beta \mathrm{CH}(22)$ \\
\hline 39 & & & 1090.71 & 1049.26 & $v \mathrm{CC}(47)+\beta \mathrm{CCC}(20)+\beta \mathrm{CH}$ (20) \\
\hline 40 & 1005 & & 1044.52 & 1004.83 & $\gamma \mathrm{CH}_{2}(97)$ \\
\hline 41 & 955 & & 996.04 & 958.19 & $\gamma \mathrm{CH}_{2}(88)$ \\
\hline 42 & & & 984.25 & 946.85 & $\gamma \mathrm{CH}_{2}(82)$ \\
\hline 43 & & & 963.84 & 927.21 & $\gamma \mathrm{CH}_{2}(80)$ \\
\hline 44 & 906 & & 944.58 & 908.69 & $\gamma \mathrm{CH}_{2}(82)$ \\
\hline 45 & & & 900.81 & 866.58 & $\gamma \mathrm{CH}(70)+\tau \mathrm{HCCCl}(25)$ \\
\hline
\end{tabular}




\begin{tabular}{|c|c|c|c|}
\hline \multicolumn{4}{|c|}{ T a b le 2 -continue } \\
\hline 46 & 882.03 & 848.52 & $\gamma \mathrm{CH}(60)+\tau \mathrm{HCCCl}(15)$ \\
\hline 47 & 843.59 & 811.54 & v $\mathrm{S}-\mathrm{NH}_{2}(67)$ \\
\hline 48 & 836.62 & 804.83 & $\gamma \mathrm{CH}(69)+\tau \mathrm{CCCl}(19)+\tau \mathrm{CCS}(12)$ \\
\hline 49 & 827.91 & 796.44 & $\gamma \mathrm{CH}(68)+\tau \mathrm{CCCl}(19)+\tau \mathrm{CCS}(10)$ \\
\hline 50 & 818.19 & 787.10 & $v \mathrm{CC}(20)+v \mathrm{CCl}(18)+v \mathrm{NS}(15)+\beta \mathrm{CCC}(10)$ \\
\hline 51 & 777.11 & 747.58 & $\tau \mathrm{CCCC}(30)+v \operatorname{CCl}(11)+v \operatorname{CS}(10)$ \\
\hline 52 & 754.52 & 725.85 & $\tau \mathrm{CCCC}(35)+\tau \mathrm{CCC}(11)+v \operatorname{CCl}(10)$ \\
\hline 53 & 741.49 & 713.31 & $\tau \operatorname{CCCC}(25)+\tau \operatorname{CCC}(11)+v \operatorname{CCl}(10)$ \\
\hline 54 & 697.83 & 671.31 & $\tau \mathrm{CCC}(54)+\tau \mathrm{CCCH}(15)+v \mathrm{CCSO}(12)$ \\
\hline 55 & 691.91 & 665.62 & $v \mathrm{CCC}(48)+\tau \mathrm{CCH}(10)+\tau \mathrm{CCSO}(12)$ \\
\hline 56 & 673.56 & 647.97 & $v \mathrm{CS}(32)+\beta \mathrm{CCC}(18)+v \mathrm{NS}(11)+v \operatorname{CCCl}(10)$ \\
\hline 57 & 658.96 & 633.92 & $v \mathrm{CS}(25)+\beta \mathrm{CCC}(15)+v \mathrm{NS}(11)+v \operatorname{CCCl}(10)$ \\
\hline 58 & 640.01 & 615.69 & $\beta \mathrm{CCC}(56)+\beta \mathrm{CCH}(17)$ \\
\hline 59 & 621.75 & 598.13 & $\tau \mathrm{HNO}(30)+v \mathrm{SN}(29)+\beta \mathrm{HNSC}(15)+\tau \mathrm{CSNH}(12)$ \\
\hline 60 & 615.03 & 591.66 & $\tau \mathrm{HNO}(28)+v \mathrm{SN}(25)+\beta \mathrm{HNSC}(10)+\tau \mathrm{CSNH}(11)$ \\
\hline 61 & 613.58 & 590.27 & $\tau \mathrm{HNO}(20)+v \mathrm{SN}(15)+\beta \mathrm{HNSC}(10)+\tau \mathrm{CSNH}(11)$ \\
\hline 62 & 579.20 & 557.19 & $\tau \mathrm{HN}(42)+v \mathrm{CCCl}(14)+v \mathrm{CS}(16)$ \\
\hline 63 & 547.65 & 526.84 & $\tau \mathrm{CSNH}(35)+\beta \mathrm{CSO}(15)+v \mathrm{CCCl}(10)$ \\
\hline 64 & 536.14 & 515.76 & $\tau \mathrm{CCCH}(28)+\tau \mathrm{CCSO}(23)+\tau \mathrm{CCCC}(13)+v \mathrm{SN}(10)$ \\
\hline 65 & 490.99 & 472.33 & $v \mathrm{CCl}(40)+v \mathrm{CS}(25)+\tau \mathrm{HNSO}(10)$ \\
\hline 66 & 474.64 & 456.61 & $v \mathrm{CCl}(35)+v \mathrm{CS}(10)+\beta \mathrm{CCC}(10)$ \\
\hline 67 & 456.44 & 439.09 & $\beta \mathrm{NSO}(32)+\tau \mathrm{CSNH}(32)+\beta \mathrm{CSO}(17)+\tau \mathrm{CCSN}(10)$ \\
\hline 68 & 447.86 & 430.84 & $\rho \mathrm{SO}_{2}(34)+\gamma \mathrm{SCC}(25)+\tau \mathrm{NH}_{2}(20)$ \\
\hline 69 & 434.43 & 417.93 & $\gamma \mathrm{CCC}(28)+\tau \mathrm{NH}_{2}(17)$ \\
\hline 70 & 400.35 & 385.14 & $\beta \mathrm{CCl}(34)+\beta \mathrm{NH}_{2}(10)$ \\
\hline 71 & 375.19 & 360.93 & $\tau \mathrm{NH}_{2}(43)+v \mathrm{C}-\mathrm{SO}_{2}(12)+\beta \mathrm{CSO}(11)$ \\
\hline 72 & 335.01 & 322.28 & $\beta \mathrm{CSN}(30)+\tau \mathrm{CCCl}(13)+\tau \mathrm{CCCS}(12)+\tau \mathrm{HCCCl}(10)$ \\
\hline 73 & 320.33 & 308.16 & $\tau \mathrm{NH}_{2}(46)+\tau \mathrm{SO}_{2}(22)$ \\
\hline 74 & 311.77 & 299.93 & $\beta \mathrm{CCCl}(68)+\tau \mathrm{HSO}(36)+\beta \mathrm{CSO}(27)$ \\
\hline 75 & 298.19 & 286.85 & $\beta \mathrm{CCCl}(57)+\tau \mathrm{HSO}(26)+\beta \mathrm{CSO}(17)$ \\
\hline 76 & 251.75 & 242.18 & $v \mathrm{CS}(38)+\beta \mathrm{CCC}(14)+v \mathrm{CCl}(10)$ \\
\hline 77 & 242.88 & 233.65 & $v \mathrm{CS}(28)+\beta \mathrm{CCC}(10)+v \mathrm{CCl}(10)$ \\
\hline 78 & 221.36 & 212.95 & $v \operatorname{CCl}(25)+v \operatorname{CS}(24)+\beta \mathrm{CCC}(13)$ \\
\hline 79 & 205.12 & 197.33 & $\beta \mathrm{CSN}(45)+\tau \mathrm{CCCl}(34)+\tau \mathrm{CCCC}(12)+\tau \mathrm{HCCCl}(10)$ \\
\hline 80 & 189.60 & 182.40 & $\beta \mathrm{CSN}(30)+\tau \mathrm{CCCl}(24)+\tau \mathrm{HCCl}(11)+\tau \mathrm{CCSO}(10)$ \\
\hline 81 & 147.90 & 142.28 & $\tau \mathrm{HNSO}(50)+\beta \mathrm{CCS}(15)+\beta \mathrm{CCCl}(12)$ \\
\hline 82 & 133.42 & 128.35 & $\tau \mathrm{NH}_{2}(93)$ \\
\hline 83 & 120.52 & 115.94 & $\tau \mathrm{NH}_{2}(90)$ \\
\hline 84 & 101.43 & 97.57 & $\tau \mathrm{CCCS}(37)+\tau \mathrm{HCCS}(15)+\tau \mathrm{CCl}(10)$ \\
\hline 85 & 62.77 & 60.39 & $\tau \mathrm{CCCS}(33)+\tau \mathrm{CCCCl}(17)+\tau \operatorname{HCCSC}(13)$ \\
\hline 86 & 55.24 & 53.15 & $\tau$ ring $\mathrm{SO}_{2}(96)$ \\
\hline 87 & 51.49 & 49.53 & $\tau$ ring $\mathrm{SO}_{2}(98)$ \\
\hline 88 & 50.21 & 48.30 & $\tau$ ring $\mathrm{SO}_{2}(99)$ \\
\hline 89 & 27.15 & 26.12 & $\tau \operatorname{CCSO}(56)+\tau \operatorname{CCSN}(40)$ \\
\hline 90 & 17.76 & 17.09 & $\tau \operatorname{CCSO}(58)+\tau \operatorname{CCSN}(39)$ \\
\hline
\end{tabular}

Abbreviations used: vs - very strong, $\mathrm{s}$ - strong, $\mathrm{m}$ - medium, $\mathrm{w}$ - weak, vw - very weak; $\mathrm{v}$ - stretching, $\alpha$ - deformation, $\mathrm{B}$ - in plane bending, $\gamma$ - out of plane bending, $\rho$ - rocking, $\omega$ - wagging and $\tau$ - twisting/torsion 


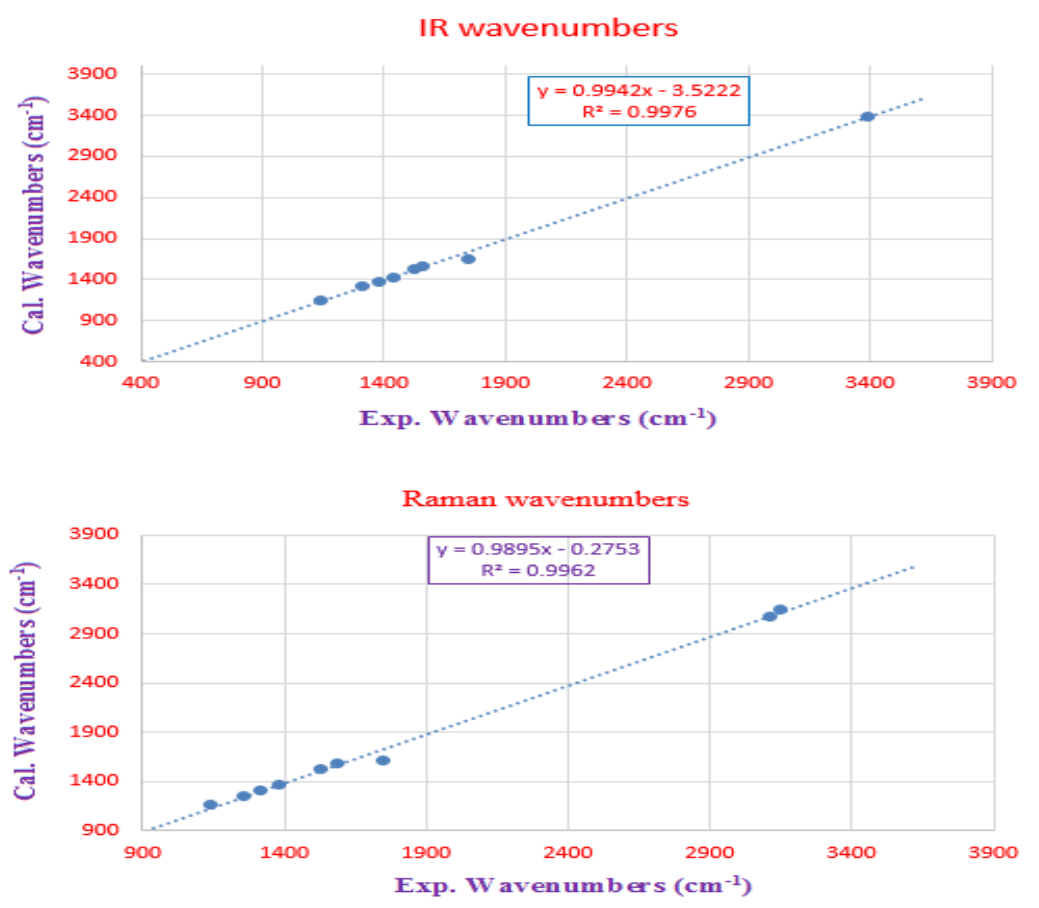

Fig. 4. Correlation graphics between experimental and calculated wavenumbers of -chloro-2-[(furan-2-ylmethyl)amino]-5-sulfamoylbenzoic acid

\subsection{1. $\mathrm{NH}_{2}$ vibration}

The high frequency region above $3000 \mathrm{~cm}^{-1}$ is the characteristic region for the ready identification of $\mathrm{C}-\mathrm{H}, \mathrm{O}-\mathrm{H}$ and $\mathrm{N}-\mathrm{H}$ stretching vibrations. In this region, the bands are not appreciably affected by the nature of the substituents [28]. The investigated molecules have an $\mathrm{NH}_{2}$ group. Hence, in the $\mathrm{NH}_{2}$ group, one symmetric and one asymmetric $\mathrm{N}$ $\mathrm{H}$ stretching vibration are expected. It is stated that the N-H stretching vibrations occur in the region $3300-3500 \mathrm{~cm}^{-1}$ [29]. Specifically, the asymmetric $\mathrm{NH}_{2}$ stretching vibration appears from 3420 to $3500 \mathrm{~cm}^{-1}$ and the symmetric $\mathrm{NH}_{2}$ stretching is observed in the range $3340-3420 \mathrm{~cm}^{-1}$ [29]. Alvareza assigned two strong bands in the IR spectra of liquid sulfamoyl fluoride and sulfamoyl chloride substances at $3418 \mathrm{~cm}^{-1}, 3312 \mathrm{~cm}^{-1}, 3386 \mathrm{~cm}^{-1}$ and $3282 \mathrm{~cm}^{-1}[25,30]$. These bands were assigned to the $\mathrm{NH}_{2}$ antisymmetric and symmetric fundamental stretching of 4-X-sulfamoylbenzoic acid $(\mathrm{X}=$ $\mathrm{F}, \mathrm{Cl}, \mathrm{Br}$, respectively) and were recorded at 3261, $3266,3240 \mathrm{~cm}^{-1}$ and $3361,3351,3330 \mathrm{~cm}^{-1}$ [31]. In this study, the symmetric $\mathrm{NH}_{2}$ stretching modes of the studied compounds were recorded in both FT-IR and FT-Raman spectra. The corresponding symmetric mode was observed at $3380 \mathrm{~cm}^{-1}$ in the FT-IR. The theoretically computed values by the B3LYP/6-31G(d,p) method were at 3484 and 3386 $\mathrm{cm}^{-1}$. As expected, these two modes are pure stretching modes as is evident from the TED column, and they are almost contributing $100 \%$. The vibrational $\mathrm{NH}_{2}$ scissoring deformation appears in the $1638-1575 \mathrm{~cm}^{-1}$ region with a strong to very strong IR intensity [32]. The strong bands in FTIR, and relatively weak bands in FT-Raman, falling in the range $1520-1542 \mathrm{~cm}^{-1}$ and described by modes 16 and 17, were assigned to $\mathrm{NH}_{2}$ scissoring. The $\mathrm{NH}_{2}$ vibrations such as wagging, rocking, and twisting, are gathered in Table 2. The stretching bands between the sulfur atom and the $\mathrm{NH}_{2}$ group were also assigned, based on the TED calculations. However, the bands observed 820 and $822 \mathrm{~cm}^{-1}$ in FT-IR and FT-Raman.

\subsection{2. $C$-H Vibration}

The aromatic compounds commonly exhibit multiple weak bands in the region $3000-3100 \mathrm{~cm}^{-1}$ [33-35]. In the present study, the hydrogen atoms around the ring give rise to the $\mathrm{C}-\mathrm{H}$ stretching modes (modes no. 40-44). As expected, all stretching vibrations are very pure modes since their TED contributions are greater than $85 \%$. The calculations also show very good agreement with the experimental results for the furosemide compound. In the aromatic compound, the $\mathrm{C}-\mathrm{H}$ in-plane bending frequencies appear in the range of $1000-1300 \mathrm{~cm}^{-1}$ and the $\mathrm{C}-\mathrm{H}$ out-of-plane bending vibrations in the range 750 to $1000 \mathrm{~cm}^{-1}$ [34]. In this work, the in- 
plane bending vibrations were recorded in the range $1377-1140 \mathrm{~cm}^{-1}$ and the out-of-plane bending vibrations in the range $796-1004 \mathrm{~cm}^{-1}$. If we consider the TED calculations, the in-plane bending vibrations are mixed modes and the out-ofplane bending vibrations are assigned as pure modes. The change in the frequency of these deformations from the values in benzene is determined, almost exclusively, by the relative position of the substituents and is almost independent of their nature [36].

\subsection{3. $\mathrm{CH}_{2}$ group vibrations}

For the assignments of $\mathrm{CH}_{2}$ group frequencies, basically six fundamentals can be associated to each $\mathrm{CH}_{2}$ group, namely: $\mathrm{CH}_{2}$ symmetric stretching; $\mathrm{CH}_{2}$ asymmetric stretching; $\mathrm{CH}_{2}$ scissoring, and $\mathrm{CH}_{2}$ rocking which belongs to in-plane vibrations and two out-of-plane vibrations, viz: $\mathrm{CH}_{2}$ wagging and $\mathrm{CH}_{2}$ twisting modes, which are expected to be depolarized [37]. The asymmetrical $\mathrm{CH}_{2}$ stretching vibrations are generally observed above $3000 \mathrm{~cm}^{-1}$, while the symmetric stretch will appear in the region between 3000 and $2900 \mathrm{~cm}^{-1}$ [38, 39]. In this study, the asymmetric and symmetric stretching vibrations are observed at 3107 , 2930 and $2880 \mathrm{~cm}^{-1}$ respectively, in FT-Raman. For n-alkyl benzenes, the assignments of the $\mathrm{C}-\mathrm{C}$ stretching mode at about $1464 \mathrm{~cm}^{-1}$ and $1290 \mathrm{~cm}^{-1}$ are quite problematic, since these bands are frequently masked by the $\mathrm{CH}_{2}$ scissoring and wagging vibrations, respectively [40, 41]. For furosemide, the $\mathrm{CH}_{2}$ scissoring mode has been assigned at $1456 \mathrm{~cm}^{-1}$ in FT-IR and $1454 \mathrm{~cm}^{-1}$ in the FT-Raman spectrum. The band at $1375 \mathrm{~cm}^{-1}$ in both the IR and Raman is assigned to the $\mathrm{CH}_{2}$ rocking in-plane vibration [42]. The $\mathrm{CH}_{2}$ wagging vibrations are observed at 1032, 984 and $906 \mathrm{~cm}^{-1}$ in the FT-IR spectra.

\subsection{4. $\mathrm{SO}_{2}$ vibration}

The asymmetric stretching for the $\mathrm{SO}_{2}, \mathrm{NH}_{2}$, $\mathrm{NO}_{2}, \mathrm{CH}_{2}$ and $\mathrm{CH}_{3}$, etc. has a magnitude higher than the symmetric stretching $[43,32]$. The symmetric and asymmetric $\mathrm{SO}_{2}$ stretching vibrations occur in the regions of $1125-1150 \mathrm{~cm}^{-1}$ and 1295 $1330 \mathrm{~cm}^{-1}$ [29]. The symmetric $\mathrm{S}=\mathrm{O}$ stretching vibrations at 1096 and $1095 \mathrm{~cm}^{-1}$, by the DFT calculations, are seen as pure modes [44], while these bands were obtained at 1153 and $1146 \mathrm{~cm}^{-1}$ in the FT-IR spectrum [45]. Dodoff [46] recorded the symmetric stretching mode at $1150 \mathrm{~cm}^{-1}$ as a strong peak, and the antisymmetric modes at 1341 and $1351 \mathrm{~cm}^{-1}$ in the infrared spectrum for $\mathrm{N}-3$ pyridinylmethanesulfonamide. In this study, the symmetric $\mathrm{S}=\mathrm{O}$ stretching vibration was at 1064 $\mathrm{cm}^{-1}$ in the infrared spectrum. The bands observed at 1310 and $1251 \mathrm{~cm}^{-1}$ in the FT-Raman spectrum, and $1316 \mathrm{~cm}^{-1}$ in the FT-IR spectrum, were assigned to antisymmetric $\mathrm{S}=\mathrm{O}$ stretching vibrations. A coincidence between the experimental values with those of the literature [44-46] and the theoretical results are found for the above conclusions. The bending vibrations of $\mathrm{O}=\mathrm{S}=\mathrm{O}$ also given in Table 2.

\subsubsection{C-Cl vibration}

The $\mathrm{C}-\mathrm{X}(\mathrm{X}=\mathrm{Cl}, \mathrm{F}, \mathrm{Br}, \mathrm{I})$ group generally gives strong bands in the frequency range 1130-480 $\mathrm{cm}^{-1}$. The position of the bands is influenced by neighboring atoms or groups. i.e. their frequencies depend on the mass and bond strength of the substitutions. Thus, the smaller the halide atom the greater is the influence of the neighbor. In mono-chlorobenzene derivatives, such as in 4-chloro-3-nitrobenzonitrile [47] and 2-amino-5-chlorobenzonitrile [48], the C-Cl stretching frequency mainly appears in the $800-600 \mathrm{~cm}^{-1}$ region $[40,49]$. Whereas, in dichlorobenzene derivatives, such as 2-amino-3,5dichlorobenzonitrile [50], the $\mathrm{C}-\mathrm{Cl}$ stretching is observed in the range $1100-400 \mathrm{~cm}^{-1}$.

\subsection{6. $C$-C vibration}

The ring carbon-carbon stretching vibration occurs in the region $1625-1430 \mathrm{~cm}^{-1}$. In general, the bands are of variable intensity and are observed at $1690-1650 \mathrm{~cm}^{-1}, 1590-1575 \mathrm{~cm}^{-1}, 1540-1470$ $\mathrm{cm}^{-1}, 1465-1430 \mathrm{~cm}^{-1}$ and $1301-1280 \mathrm{~cm}^{-1}$, as given by Varsanyi [51] for the fine bands in this region. In the present work, the wavenumbers of the very strong band observed in the FT-IR spectrum at 1650,1556, 1423, 1373 and $1316 \mathrm{~cm}^{-1}$ have been assigned to the $\mathrm{C}-\mathrm{C}$ stretching vibrations in furosemide. The same vibrations appear in the FT-Raman spectrum for furosemide at 1607, 1583, 1370,1310 and $1251 \mathrm{~cm}^{-1}$. The theoretically computed values for furosemide by B3LYP/6-31G(d,p) methods at 1748, 1595, 1583, 1554, 1437, 1377, 1312 and $1271 \mathrm{~cm}^{-1}$ showed excelled agreement with the experimental data. The in-plane deformation vibration is at higher wave numbers than the out-of-plane vibrations. Shimanouchi et al. [52] gave the wave numbers data for these vibrations for different benzene derivatives from normal coordinate analysis. The theoretically computed values by the DFT method show excellent agreement 
with the experimental data. Small changes observed in the wavenumbers for these modes are due to the change in force constant/reduced mass ration resulting mainly from the extent of mixing between the ring and the substitution group [53].

\subsection{UV-VIS spectral analysis}

The time dependent density functional method (TD-DFT) is able to detect accurate absorption wavenumbers at a relatively small computing time which corresponding vertical electronic transitions computed on the ground state geometry, especially in the study of the solvent effect [5456]. Experimentally, the electronic transitions bands were at 230 and $305 \mathrm{~nm}$. Theoretically, the three intense electronic transitions were predicted at $269.58 \mathrm{~nm}(f=0.0000), 315.99 \mathrm{~nm}(f=0.0117)$, and $324.13 \mathrm{~nm}(f=0.0893)$, which agree with the experimental data. The molecular orbitals involved in these electronic transitions are shown in Figure 5. Both electronic transitions are $\pi \rightarrow \pi^{*}$ excitations.

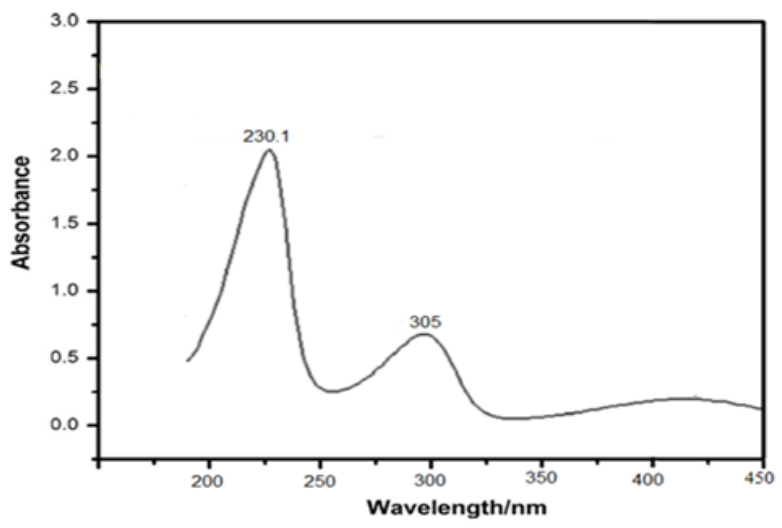

Fig. 5. Experimental UV-Vis spectra of 4-chloro-2-[(furan-2ylmethyl)amino]-5-sulfamoylbenzoic acid using TD-DFT/B3LYP/6-31G(d,p) method.

\subsection{Frontier molecular orbital analysis}

Molecular orbitals (HOMO and LUMO) and their properties, such as energy, are very useful for physicists and chemists and are very important parameters for quantum chemistry. This is also used by the frontier electron density for predicting the most reactive position in $\pi$-electron systems, and also explains several types of reaction in conjugated systems [57]. The conjugated molecules are characterized by a small highest occupied molecular orbital-lowest unoccupied molecular orbital (HOMO-LUMO) separation, which is the result of a significant degree of intramolecular charge transfer from the end-capping electron-donor groups to the efficient electron-acceptor groups through the $\pi$ conjugated path [58]. Both the highest occupied molecular orbital-lowest unoccupied molecular orbital are the main orbitals that takes part in chemical stability [59].

The HOMO represents the ability to donate an electron, and LUMO as an electron acceptor represents the ability to obtain an electron. The HOMO and LUMO energy calculated by the B3LYP/6-31G $(d, p)$ method is shown below. This electronic absorption corresponds to the transition from the ground to the first excited state and is mainly described by one electron excitation from the highest occupied molecular orbital to the lowest unoccupied molecular orbital. While the energy of the HOMO is directly related to the ionization potential, LUMO energy is directly related to the electron affinity. The energy difference between the HOMO and LUMO orbitals is called the energy gap and is an important stability for structures [60]. Recently, the energy gap between HOMO and LUMO has been used to prove the bioactivity from intramolecular charge transfer [61, 62]. The plots of the highest HOMOs and LUMOs are shown in Figure 6.

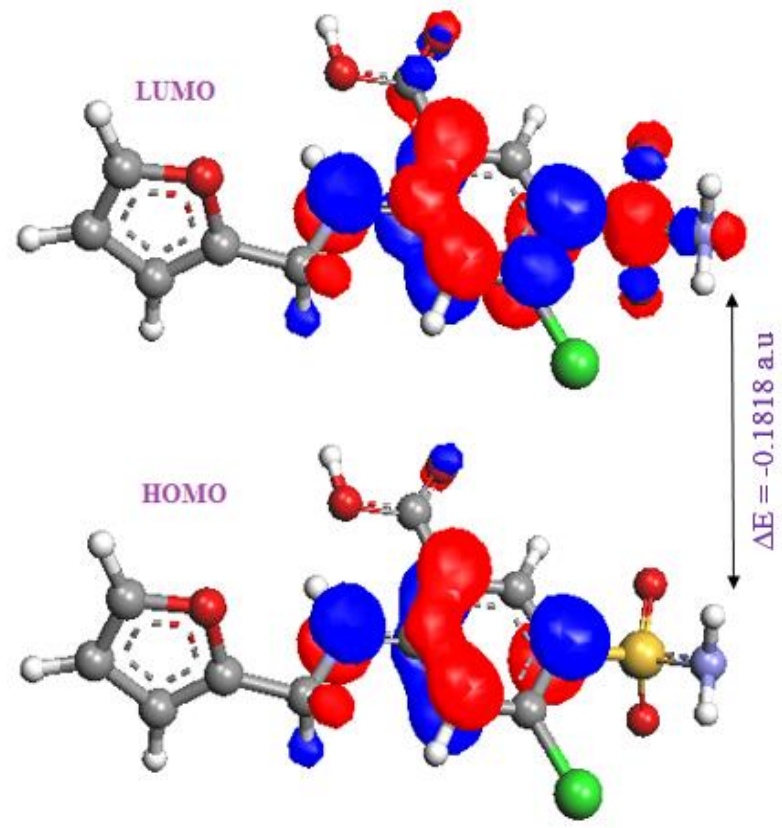

Fig. 6. Frontier molecular orbital of 4-Chloro-2-[(furan-2ylmethyl)amino]-5-sulfamoylbenzoic acid molecule

The HOMO is located over the chlorosulfamoyl benzoic acid ring, and the HO$\mathrm{MO} \rightarrow$ LUMO transition implies an electron density transfer to the amino group from the chlorosulfamoyl benzoic acid ring and lower in the HOMO and LUMO energy gap explains the eventual 
charge transfer interactions taking place within the molecule

$$
\begin{aligned}
& \text { HOMO energy }(B 3 L Y P)=-0.24699 \text { a.u } \\
& \text { LUMO energy }(B 3 L Y P)=-0.06519 \text { a.u }
\end{aligned}
$$

HOMO-LUMO energy gap (B3LYP $)=-0.1818$ a.u

\subsection{Global reactivity descriptors}

Based on the density functional descriptors, global chemical reactivity descriptors of the furosemide molecule such as ionization potential $(I)$, electron affinity $(A)$, chemical potential $(\mu)$, electronegativity $(\chi)$, global hardness $(\eta)$, global softness $(\sigma)$ and global electrophilicity $(\omega)$ values can be described as follows $[63,64]$. In simple molecule orbital theory approaches, the HOMO energy $\left(E_{\mathrm{HOMO}}\right)$ is related to the ionization potential by Koopman's theorem and the LUMO energy $\left(E_{\mathrm{LU}}\right.$ мо) has been used to estimate the electron affinity.

$$
\begin{aligned}
& I=-E_{\text {Hомо }} \\
& A=-E_{\text {LUMO }}
\end{aligned}
$$

The average value of the HOMO and LUMO energy is related to the electronegativity defined by Mulliken [67].

$$
\chi=(I+A) / 2
$$

In addition, the HOMO and LUMO energy is related to the hardness ( $\eta$ ) and softness $(\sigma)$ [60]

$$
\begin{gathered}
\eta=(I-A) / 2 \\
\sigma=1 / \eta
\end{gathered}
$$

Global electrophilicity $(\omega)$ is defined as: [65]

$$
\omega=-\mu^{2} / 2 \eta
$$

where $\mu$ is the chemical potential which takes the average value of the ionization potential $(I)$ and electron affinity $(A)[66]$

$$
\mu=-(I+A) / 2
$$

The electronic chemical potential is the parameter which describes the tendency of electrons to escape from an equilibrium system. Thus, the

\begin{tabular}{|c|c|c|c|c|c|c|c|c|c|}
\hline $\begin{array}{l}\text { Molecular } \\
\text { Properties }\end{array}$ & $\begin{array}{l}\text { Energy } \\
\text { (a.u) }\end{array}$ & $\begin{array}{c}\text { Energy gap } \\
(\mathrm{eV})\end{array}$ & $\begin{array}{c}\text { Ionization } \\
\text { potential }(I)\end{array}$ & $\begin{array}{c}\text { Electron } \\
\text { affinity }(A)\end{array}$ & $\begin{array}{c}\text { Global } \\
\text { hardness } \\
(\eta) \\
\end{array}$ & $\begin{array}{c}\text { Electro } \\
\text { negativity } \\
(\chi) \\
\end{array}$ & $\begin{array}{c}\text { Global } \\
\text { softness } \\
(\sigma) \\
\end{array}$ & $\begin{array}{c}\text { Chemical } \\
\text { potential } \\
(\mu)\end{array}$ & $\begin{array}{c}\text { Global } \\
\text { electriphilicity } \\
(\omega) \\
\end{array}$ \\
\hline \multicolumn{10}{|c|}{ B3LYP/6-311G(d,p) } \\
\hline $\begin{array}{l}\text { HOMO } \\
\text { LUMO }\end{array}$ & $\begin{array}{l}-0.24699 \\
-0.06519\end{array}$ & -0.1818 & 0.1818 & 0.0651 & 0.0583 & 0.1234 & 17.1526 & -0.0583 & 0.4848 \\
\hline $\begin{array}{l}\text { HOMO } \\
\text { LUMO+1 }\end{array}$ & $\begin{array}{l}-0.24699 \\
-0.02727\end{array}$ & -0.21972 & 0.2197 & 0.0272 & 0.0962 & 0.1234 & 10.3950 & -0.0962 & 0.4972 \\
\hline $\begin{array}{l}\text { HOMO } \\
\text { LUMO+2 }\end{array}$ & $\begin{array}{l}-0.24699 \\
-0.01073\end{array}$ & -0.23621 & 0.2362 & 0.0107 & 0.1127 & 0.1234 & 8.8731 & -0.1127 & 0.5000 \\
\hline
\end{tabular}
frontier molecular orbital analysis also provides details on the chemical stability, chemical hardness and electronegativity of the molecule, the results of which from the B3LYP/6-31G(d,p) basis set are presented in Table 3.

Table 3

Comparison of HOMO, LUMO energy gaps and related molecular properties of

4-Chloro-2-[(furan-2-ylmethyl)amino]-5-sulfamoylbenzoic acid at B3LYP/6-3G(d,p) level of theory

\subsection{Mulliken analysis}

Charge distributions of the molecules have been calculated by performing a Mulliken analysis [67].The theoretically calculation of atomic charges plays an important role in the application of quantum mechanical calculations to molecular systems. The calculated results reveal that the negative charge is delocalized between the carbon and nitrogen atoms. For the hydrogen atoms, the dif- ferences in the calculated charges are relatively smaller. It is worth mentioning that the largest values of charge are noticed for $\mathrm{H} 24$ and $\mathrm{H} 27$ which are involved in hydrogen bonding $(0.3356 \mathrm{e}$ and $0.3051 \mathrm{e}$, respectively). Large values of charge on $\mathrm{N} 3$ (negative) and S10 (positive) are due to the intramolecular charge transfer which occurs within the molecule. Figure 7 shows that the natural atomic charges are more sensitive to the changes in the molecular structure than Mulliken's net charges. 


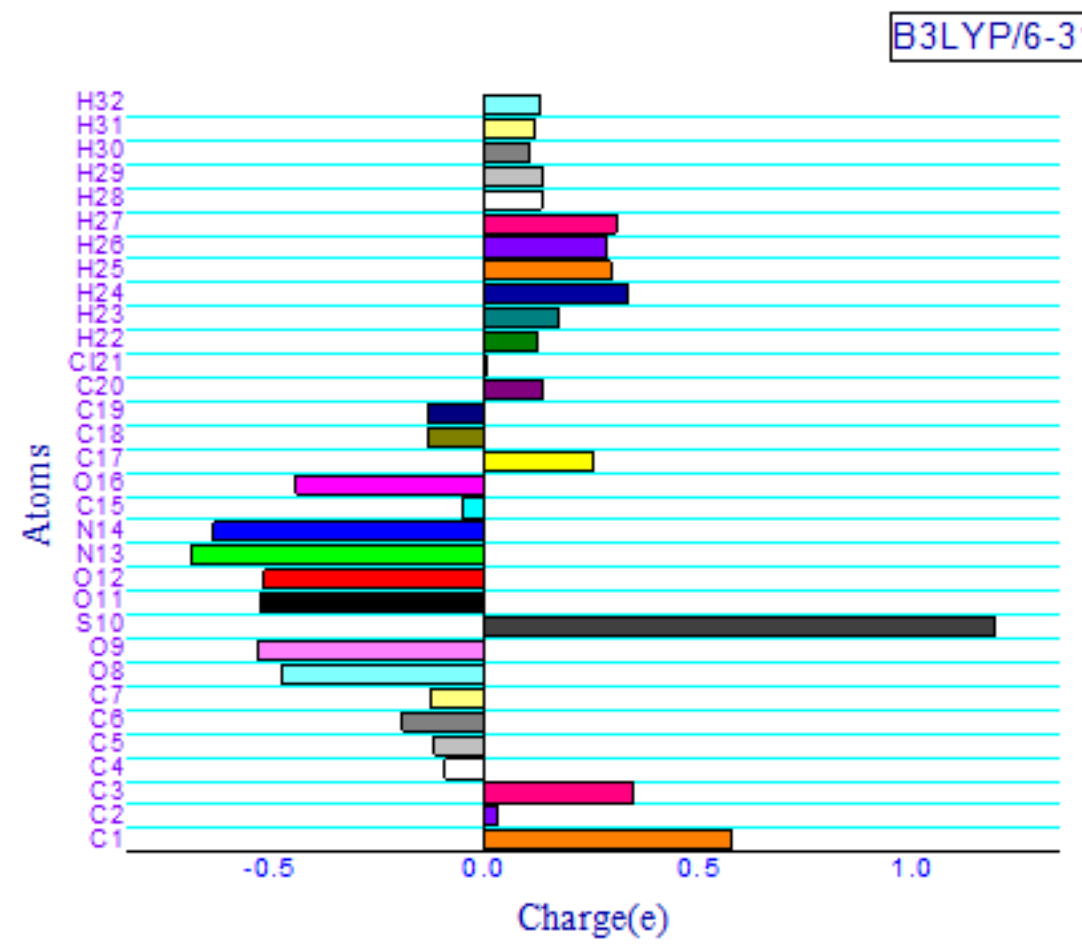

Fig. 7. The historam of calculated Mulliken charge for 4-chloro-2-[(furan-2-ylmethyl)amino]-5-sulfamoylbenzoic acid molecule

\subsection{Molecular electrostatic potential}

Molecular electrostatics is used extensively for interpreting potentials and predicting the reactive behavior of a wide variety of chemical systems in both electrophilic and nucleophilic reactions, the study of biological recognition processes, and hydrogen bonding interactions [68]. To predict reactive sites for electrophilic and nucleophilic attack for the investigated compound, the Molecular Electrostatic Potential (MEP) was calculated at B3LYP/6-31G(d,p). The different values of the electrostatic potential at the surface are represented by different colors; red represents the region of most electro-negative electrostatic potential, blue represents the region of the most positive electrostatic potential, and green represents the region of zero potential. The potential decreases in the order red < orange < yellow < green < blue. The MEP surface provides the necessary information about the reactive sites. The total electron density on to which the MEP has been mapped is shown in Fig.8 This figure provides a visual representation of the chemically active sites and the comparative reactivity of the atoms [69]. The electrophilic reactivity is related to the negative region and the nucleophilic reactivity is related to the positive one, as can be seen from the MEP of the candidate molecule. The major positive potential region around the hydrogen atom of the hydroxyl group, characterized by a blue color, indicates the site for nucle- ophilic attack while rest of the region is almost neutral, characterized by the green color.

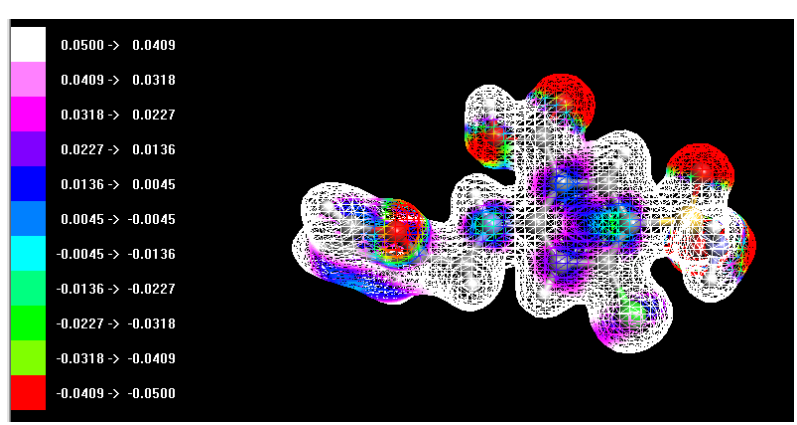

Fig. 8. 3D plots of the molecular electrostatic potential for 4-Chloro-2-[(furan-2-ylmethyl)amino]-5-sulfamoylbenzoic acid molecule

\subsection{Thermodynamic analysis}

In order to understand the thermodynamic behavior of the furosemide compound, the thermodynamic parameters (such as zero point vibrational energy, thermal energy, specific heat capacity, rotational constants, entropy and dipole moment) of 4M4M2PO were calculated by DFT/B3LYP method using 6-31G basis set at $298.15 \mathrm{~K}$ and $1 \mathrm{~atm}$ pressure, and are presented in Table 4 . These functions describe the thermodynamic stability of the system at given conditions of pressure and temperature [70]. 
Table 4

Calculated thermodynamic parameters

of 4-chloro-2-[(furan-2-ylmethyl)amino]-5sulfamoylbenzoic acidat $298.15 \mathrm{~K}$

\begin{tabular}{lc}
\hline \hline \multicolumn{1}{c}{ Parameters } & B3LYP/6-3G(d,p) \\
\hline SCF energy (a.u) & -1807.822 \\
\hline Total energy + ZPE (AU) & 0.229 \\
\hline Gibbs Free energy (AU) & 0.178 \\
\hline Rotational constants (GHz) & 0.889 \\
& 2.981 \\
& 35.142 \\
\hline Entropy (cal mol $\left.{ }^{-1} \mathrm{~K}^{-1}\right)$ & 156.034 \\
\hline Total & 0.889 \\
\hline Translational & 0.889 \\
\hline Rotational & 154.257 \\
\hline Vibrational & $\mu_{\mathrm{x}}=-9.151$ \\
\hline & $\mu_{\mathrm{y}}=-2.424$ \\
Dipole moments, $\mu$ (Debyes) & $\mu_{\mathrm{z}}=3.259$ \\
& $\mu_{\text {Total }}=10.012$ \\
\hline \hline
\end{tabular}

The dipole moment of a molecule is an important property and it helps to study the intermolecular interactions involving the non-bonded type dipole-dipole interactions, because the higher the dipole moment, the stronger the intermolecular interactions [71]. Furthermore, the dipole moment can be used to describe the charge movement across the molecule. The direction of the dipole moment vector in a molecule depends on the centers of negative and positive charges. The dipole moment of furosemide obtained in $6-31 \mathrm{G}$ basis set is $10.012 \mathrm{D}$.

\section{CONCLUSIONS}

In the present study, the molecular structure and vibrational frequencies have been studied using DFT (B3LYP) calculations with the 6$31 \mathrm{G}(\mathrm{d}, \mathrm{p})$ basis set. The final optimized structure is in good agreement with the experimental structure. The experimental derivations between the models can be attributed to the differences between the calculation and the experimental measurements, i.e., gas phase and solid phase. The FT-IR and FTRaman spectra of the studied compound were calculated and assigned based on the total energy distribution. The calculations show that using the TDDFT/6-31G $(\mathrm{d}, \mathrm{p})$ approach, the experimental absorption spectrum has been well reproduced. It has been concluded that the lowest singlet excited state of the furosemide molecule is mainly derived from the HOMO $\rightarrow$ LUMO $\left(\pi \rightarrow \pi^{*}\right)$ electronic transitions.
A molecular electrostatic potential map and global reactivity parameters were used to describe the chemical reactivity of the studied molecule.

\section{REFERENCES}

[1] F. O. Simsek, M. S Kaynak, N. Sanil \& S. Sahin, Determination of amlodipine and furosemide with newly developed and validated RP-HPLC method in commercially available tablet dosage forms, Hacettepe University Journal of the Faculty of Pharmacy, 32(2), 145-158 (2012).

[2] C. T. Supuran, A. Scozzafava, Carbonic anhydrase inhibitors, Curr. Med. Chem., Immunol., Endocrine Metabolic Agents, 1, 61-97 (2001). DOI: $10.2174 / 1568013013359131$

[3] C. T. Supuran, A. Scozzafava, A. Casini, Carbonic anhydrase inhibitors, Med. Res. Rev., 23, 146-189 (2003). DOI: $10.1002 /$ med.10025

[4] C. T. Supuran, A. Scozzafava, Applications of carbonic anhydrase inhibitors and activators in therapy, Expert Opin. Ther. Patents, 12, 217-242 (2002).

DOI.org/10.1517/13543776.12.2.217

[5] J. Niessen, U. Schoder, M. Rosenbaum, F.Scholz, Fluorinated polyanilines as superior materials for electrocatalytic anodes in bacterial fuel cells, Electrochemistry Communications, 3, 571-575 (2004). DOI.org/10.1016/j.elecom.2004.04.006

[6] N. Sundaraganesan, J. Karpagam, S. Sebastian, J. P. Cornard, The spectroscopic (FTIR, FT-IR gas phase and FT-Raman), first order hyperpolarizabilities, NMR analysis of 2,4-dichloroaniline by ab initio HF and density functional methods, Spectrochimica Acta Part A: Molecular and Biomolecular Spectroscopy, 73, 1119-1122 (2009). DOI.org/10.1016/j.saa.2009.01.007

[7] M. Karabacak, D. Karagoz, M. Kurt, Experimental (FTIR and FT-Raman spectra) and theoretical (ab initio HF, DFT) study of 2-chloro-5-methylaniline, Journal of Molecular Structure, 892, 25-31 (2008). DOI.org/10.1016/j.molstruc.2008.04.054

[8] A. Altun, K. Golcuk, M. Kumru, Structure and vibrational spectra of p-methylaniline: Hartree-Fock, MP2 and density functional theory studies, Journal of Molecular Structure: THEOCHEM, 637, 155-169 (2003). DOI.org/10.1016/S0166-1280(03)00531-1

[9] M. Govindarajan, M. Karabacak, S. Periandy, D. Tanuj, Spectroscopic (FT-IR, FT-Raman, UV and NMR) investigation and NLO, HOMO-LUMO, NBO analysis of organic 2,4,5-trichloroaniline, Spectrochimica Acta Part A: Molecular and Biomolecular Spectroscopy, 97, 231245 (2012). DOI.org/10.1016/j.saa.2012.06.014

[10] M. Karabacak, D. Karagoz, M. Kurt, FT-IR, FT-Raman vibrational spectra and molecular structure investigation of 2-chloro-4-methylaniline: A combined experimental and theoretical study, Spectrochimica Acta Part A: Molecular and Biomolecular Spectroscopy, 72, 1076-1083 (2009). DOI.org/10.1016/j.saa.2008.12.047

[11] P. Wojciechowski, K. Helios, D. Michalska, Vib. Spectr., 57, 126-134 (2011). 
[12] H. Wang, B. Liu, J. Wan, J. Xu, X. Zheng, Excited-state structural dynamics and vibronic coupling of 1,3dithiole-2-thione-resonance Raman spectroscopy and density functional theory calculation study, J. Raman Spectrosc, 40, 992-997 (2009). DOI: 10.1002/jrs.2216

[13] H. Wang, J. Xu, J. Wan, Y. Zheno, X. Zheng, Excited state structural dynamics of tetra(4-aminophenyl)porphine in the condensed phase: resonance Raman spectroscopy and density functional theory calculation study, J. Phys Chem. B, 114, 3623-3632 (2010). DOI: $10.1021 /$ jp 1000978

[14] Gaussian Inc., Gaussian 09 Program, Gaussian Inc. Wallingford, 2009.

[15] H. B. Schlegel, Optimization of equilibrium geometries and transition structures, J. Comput. Chem., 3, 214-218 (1982). DOI: $10.1002 /$ jcc.540030212

[16] J. Baker, A. A. Jarzecki, P. Pulay, Direct scaling of primitive valence force constants: An alternative approach to scaled quantum mechanical force fields, $J$. Phys. Chem., 102 A, 1412-1424 (1998). DOI: $10.1021 /$ jp980038m

[17] P. Pulay, J. Baker, K. Wolinski, Reply to the comments on Efficient calculation of canonical MP2 energies' by A. Kohn and C. Hattig, Chem. Phys. Lett., 358, 354-356 (2002). DOI.org/10.1016/S0009-2614(02)00610-3

[18] F. Weinhold, Gauss view, J. Am. Chem. Phys. Soc., 102, 7211 (1980).

[19] J. V. Prasad, S. S. Rai, S. N. Thakuk, Overtone spectroscopy of benzene derivatives using thermal lensing, Chem. Phys. Lett. 164 (6), 629-634 (1989). DOI.org/10.1016/0009-2614(89)85272-8

[20] K. M. Gough, B. R. Henry, Carbon-hydrogen stretching overtone spectra of nitrobenzene and its deuterated derivatives. Assignment of the ortho carbon-hydrogen bond, J. Phys. Chem.,87, 3804-3805 (1983). DOI: $10.1021 / \mathrm{j} 100243 \mathrm{a} 003$

[21] M. K. Ahmed, B. R. Henry, Gas-phase overtone spectral investigation of structurally and conformationally nonequivalent carbon-hydrogen bonds in trimethylbenzenes, J. Phys. Chem. 90, 1737-1739 (1986). DOI: $10.1021 / \mathrm{j} 100400 \mathrm{a} 002$

[22] M. S. Dewar, P. J. Grisdale, J. Am. Chem. Soc. 84, 3539 (1962).

[23] B. G. Johnson, P. M. Gill, J. A. Pople, The performance of a family of density functional methods, J. Chem. Phys., 98, 5612 (1993). DOI.org/10.1063/1.464906

[24] B. T. Gowda et al., ActaCryst. E63, 2967 (2007).

[25] B. M. S. Alvareza, M. I. M. Valdeza, E. H. Cultin, C. O. D. Vedova, Spectroscopic and theoretical studies of sulfamoil fluoride, $\mathrm{FSO}_{2} \mathrm{NH}_{2}$ and $\mathrm{N}$-(fluorosulfonyl) im-

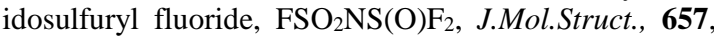
291-300 (2003).

DOI.org/10.1016/S0022-2860(03)00407-1

[26] M. F. Erben, C. O. D. Vedova, R. Boese, H. Willner, C. Leibold, H. Oberhammer, Trifluoromethyl chlorosulfonate, $\mathrm{CF}_{3} \mathrm{OSO}_{2} \mathrm{Cl}$ : Gas phase and crystal structure, conformation and vibrational analysis studied by experimental and theoretical methods, Inorganic chemistry, 42, 7297-7303 (2003). DOI: 10.1021/ic034531a
[27] M. E. Tuttolomondo, P. E. Arganaraz, E. L. Varetti, S. A. Hayes, D. A. Wann, H. E. Robertson, D. W.N. Rankin, A. B. Altabef, Gas-phase structure and vibrational properties of trifluoromethyl trifluoromethanesulfonate, $\mathrm{CF}_{3} \mathrm{SO}_{2} \mathrm{OCF}_{3}$, Eur. J. Inorg. Chem., 10, 1381-1389 (2007). DOI: 10.1002/ejic.200600940

[28] M. Silverstein, G. C. Basseler, C. Morill, Spectrometric identification of organic compounds, Wiley, Newyork, 1981.

[29] L. J. Bellamy, The Infrared Spectra of Complex Molecules, vol.2, Chapman and Hall, London, 1980.

[30] R. M. S. Alvareza, E. H. Cutin, C. O. D. Vedova, Vibrational studies of sulfamoil chloride $\left(\mathrm{ClSO}_{2} \mathrm{NH}_{2}\right), \mathrm{J}$. Mol. Struct. 440, 213-219 (1998). DOI.org/10.1016/S0022-2860(97)00260-3

[31] B. T. Gowda, K. Jyothi, J. D. D. Souza, Journal for Nature Research, 57a (2002) 967-973.

[32] D. Lin-Vien, N. B. Colthup, W. G. Fateley, J. G. Grasselli, The Handbook of Infrared and Raman Characteristic Frequencies of Organic Molecules, Academic Press, Boston, MA, 1974.

[33] M. Silverstein, G. C. Basseler, C. Morill, Spectrometric identification of organic compounds, Wiley, New York, 1981.

[34] G. Varsanyi, Assignments of vibrational spectra of 700 benzene derivatives, Wiley, New York, 1974, pp. 280.

[35] A. Altun, K. Golcuk, M. Kumru, Theoretical and experimental studies of the vibrational spectra of $\mathrm{m}$ methylaniline, J. Mol. Struct. (Theochem.), 625, 17-24 (2003). DOI.org/10.1016/S0166-1280(02)00698-X

[36] N. Sundaraganesan, H. Saleem, S. Mohan, Vibrational spectra, assignments and normal coordinate analysis of 3-aminobenzyl alcohol, Spectrochim. Acta A, 59, 25112517 (2003). DOI.org/10.1016/S1386-1425(03)00037-4

[37] N. B. Colthup, L. H. Daly, S. E. Wiberley, Introduction to Infrared and Raman spectroscopy, Academic Press, New York, 1990.

[38] S. Muthu, E. I. Paulraj, Solid State Sci., 14, 476-487 (2012).

[39] D. Sajan, J. Binoy, B. Pradeep, K. V. Krishna, V. B. Kartha, I. H. Joe, V. S. Jayakumar, Spectrochim. Acta A 60, 173-180 (2004).

[40] S. Muthu, N. R. Sheela, S. Sampathkrishnan, Mol. Sim$u l .$, 37, 1276-1288 (2011).

[41] K. B. Wiberg, A. Sharke, Spectrochim. Acta A, 29, $583-$ 594 (1973).

[42] V. Krishnakumar, N. Surumbarkuzhali, S. Muthunatesan, Spectrochim. Acta A, 71, 1810-1813 (2009).

[43] M. Karabacak, M. Cinar, Z. Unal, M. Kurt, FT-IR, UV spectroscopic and DFT quantum chemical study on the molecular conformation, vibrational and electronic transitions of 2-aminoterephthalic acid, J.Mol.Struct., 982 22-27 (2010).

DOI.org/10.1016/j.molstruc.2010.07.033

[44] M. Karabacak, M. Cinar, M. Kurt, DFT based computational study on the molecular conformation, NMR chemical shifts and vibrational transitions for $\mathrm{N}-(2-$ methylphenyl) methanesulfonamide and N-(3- 
methylphenyl) methanesulfonamide, J. Mol. Struct, 968, 108-114 (2010).

DOI.org/10.1016/j.molstruc.2010.01.033

[45] K. L. Jayalaksmi, B. T. Gowda, Synthetic, infrared and NMR $\left({ }^{1} \mathrm{H}\right.$ and $\left.{ }^{13} \mathrm{C}\right)$ spectral studies of $\mathrm{n}$-(substituted phenyl)-methanesulphonamides, Journal for Nature Research, 59a, 491-500 (2004).

DOI: 0932-0784 / 04 / 0700-049

[46] N. I. Dodoff, Vib. Spectrosc. 4(3), 5-9 (2000).

[47] Y. Sert, C. Cirak, F. Ucun, Vibrational analysis of 4chloro-3-nitrobenzonitrile by quantum chemical calculations, Spectrochim. Acta A, 107, 248-255 (2013). DOI.org/10.1016/j.saa.2013.01.046

[48] B. Lakshmaiah, G. R. Rao, Vibrational analysis of substituted anisoles. I-Vibrational spectra and normal coordinate analysis of some fluoro and chloro compounds, $J$. RamanSpectrosc., 20, 439-448 (1989). DOI: $10.1002 / j \mathrm{js} .1250200709$

[49] J. A. Fanitan, I. Iweibo, R. A. Oderinde. J. Raman Spectrosc. 11, 6 (1998).

[50] V. K. Rastogi, M. Alcolea Palafox, R. Tomar, 2-Amino3,5-dichlorobenzonitrile: DFT calculations in the monomer and dimer forms, FT-IR and FT-Raman spectra, molecular geometry, atomic charges and thermodynamical parameters, Spectrochim Acta A, 110, 458-470 (2013). DOI.org/10.1016/j.saa.2013.03.026

[51] G. Varsanyi, Assignments of Vibrational Spectra of Benzene Derivatives, Academic Press, New York, 1969.

[52] T. Shimanouchi, Y. Kalkiuti, I. Gamo, Stability and burning velocities of laminar carbon monoxide-air flames at pressures up to 93 atmospheres, J. Chem. Phys. 25, 12411245 (1956). DOI.org/10.1063/1.1743186

[53] V. Balachadran, V. Karpagam, A. Lakshmi, Conformational stability, theoretical and experimental vibrational spectral analysis of 2,4,6-trihydroxybenzaldehyde, $J$. Mol. Struct. 1021, 13-21 (2012).

DOI.org/10.1016/j.molstruc.2012.04.070

[54] D. Jacquemin, J. Preat, E. A. Perpete, A TD-DFT study of the absorption spectra of fast dye salts, Chem. Phys. Lett. 410, 254-259 (2005). DOI.org/10.1016/j.cplett.2005.05.081

[55] D. Jacquemin, J. Preat, M. Charlot, V. Wathelet, J. M. Andre, E. A. Perpete, Theoretical investigation of substituted anthraquinone dyes, J. Chem. Phys. 121 17361746 (2004). DOI: 10.1063/1.1764497

[56] M. Cossi, V. Barone, Time-dependent density functional theory for molecules in liquid solutions, J. Chem. Phys., 115, 4708 (2001). DOI.org/10.1063/1.1394921

[57] K. Fukui, T. Yonezewa, H. Shingu, A molecular orbital theory of reactivity in aromatic hydrocarbons, J. Chem. Phys, 20, 722 (1952). DOI.org/10.1063/1.1700523

[58] C. H. Choi, M. Kertesz, Conformational Information from Vibrational Spectra of Styrene, trans-Stilbene, and cis-Stilbene, J. Phys. Chem. 101 (20), 3823-3831 (1997). DOI: 10.1021/jp970620v

[59] S. Gunasekeran, R. A. Balaji, S. Kumeresan, G. Anand, S. Srinivasan, Experimental and theoretical investiga- tions of spectroscopic properties of N-acetyl-5methoxytryptamine, Can. J. Anal. Sci. Spectrosc, 53, 149-160 (2008).

[60] D. F. Lewis, C. Loannides, D. V. Pake, Interaction of a series of nitriles with the alcohol-inducible isoform of P450: Computer analysis of structure - activity relationships, Xenobiotica, 24, 401-408 (1994). DOI.org/10.3109/00498259409043243

[61] L. Padmaja, C. Ravikumar, D. Sajan, I. H. Joe, V. S. Jayakumar, G. R. Pettit, O. F. Nielson, Density functional study on the structural conformations and intramolecular charge transfer from the vibrational spectra of the anticancer drug combretastatin-A2, J. Raman Spectrosc, 40, 419-428 (2009). DOI: 10.1002/jrs.2145

[62] C. Ravikumar, I. H. Joe, V. S. Jayakumar, Charge transfer interactions and nonlinear optical properties of pushpull chromophore benzaldehyde phenylhydrazone: a vibrational approach, Chem. Phys. Lett. 460, 552-558 (2008). DOI.org/10.1016/j.cplett.2008.06.047

[63] P. Politzer \& J. S. Murray, The fundamental nature and role of the electrostatic potential in atoms and molecules, Theor. Chem. Acc., 108, 134-142 (2002). DOI.org/10.1007/s00214-002-0363-9

[64] R. G. Pearson, Chemical Hardness, John Wiley-VCH, Weinheim, New York, 1997.

[65] R. G. Parr, V. Laszlo, Szentpály \& S. Liu, Electrophilicity Index, J. Am. Chem. Soc, 121, 1922-1924 (1999). DOI: $10.1021 /$ ja983494x

[66] J. Padmanabhan, R. Parthasarathi, V. Subramanian \& P.K. Chattaraj, Electrophilicity-based charge transfer descriptor, J. Phys. Chem, A, 111, 1358-1361 (2007). DOI: $10.1021 /$ jp0649549

[67] R. S. Mulliken, Electronic population analysis on LCAOMO molecular wave functions. I, J. Chem. Phys, 23, 1833-1840 (1955). DOI.org/10.1063/1.1740588

[68] P. Polizer, J. S. Murry, Theoretical biochemistry and molecular biophysics: a comprehensive survey, in: D. I. Beveridge, R. Lavery (Eds.), Electrostatic Potential Analysis of Dibenzo - p-dioxins and Structurally Similar System in Relation to Their Biological Activities, Protein, Vol.2, Academic Press, Schenectady, NY, 1991, Chapter 13

[69] V. P. Gupta, A. Sharma, V. Virdi, V. J. Ram, Structural and spectroscopic studies on some chloropyrimidine derivatives by experimental and quantum chemical methods, Spectrochim Acta Part A, 64, 57-67 (2006). DOI.org/10.1016/j.saa.2005.06.045

[70] Z. Ran, D. Baotong, S. Gang, S. Yuxi, Experimental and theoretical studies on $\mathrm{o}-, \mathrm{m}-$ and p-chlorobenzylideneaminoantipyrines, Spectrochim Acta Part A, 75, 1115-1124 (2010). DOI.org/10.1016/j.saa.2009.12.067

[71] O. Prasad, L. Sinha, N. Kumar, Theoretical Raman and IR spectra of tegafur and comparison of molecular electrostatic potential surfaces, polarizability and hyerpolarizability of tegafur with 5-fluoro-uracil by density functional theory, J. At. Mol. Sci, 1, 201-214 (2010). DOI: $10.4208 /$ jams.032510.042010a 